\section{M \\ VIA MEDICA www.fr.viamedica.pl}

\title{
Doświadczenia własne w zastosowaniu tocilizumabu w leczeniu chorych na reumatoidalne zapalenie stawów
}

\section{Application of tocilizumab in managemenent of patients with theumatoid arthritis: a single centre experience}

\section{STRESZCZENIE}

Wstęp: Praca stanowi podsumowanie doświadczeń w leczeniu tocilizumabem chorych na reumatoidalne zapalenie stawów, pacjentów Katedry i Kliniki Chorób Wewnętrznych, Reumatologii i Immunologii Klinicznej Śląskiego Uniwersytetu Medycznego w Katowicach w latach 2012-2019.

Material i metody: Ogótem leczeniem tym lekiem objęto około 70 chorych, z czego obecnie ponad 50 jest leczonych aktywnie. Większość pacjentów otrzymuje tocilizumab w tak zwanej drugiej linii leczenia po niepowodzeniu inhibitorów TNF-alfa.

Wyniki: U wszystkich chorych uzyskano dobrą odpowiedź na leczenie po pierwszych 90 dniach stosowania leku. Niska aktywność choroby bądź remisja utrzymywały się przez cały okres leczenia niezależnie od stosowania leku łącznie z metotrekastem czy stosowania go w monoterapii. Leczenie przebiega z małą liczbą przypadków działań niepożądanych.

Wnioski: Doświadczenia własne uzyskane z badania stosunkowo małej liczby chorych, ale odzwierciedlające praktykę lekarską (tzw. real world data) są zgodne z wynikami badań klinicznych i potwierdzają, że tocilizumab, rekombinowane humanizowane przeciwciało monoklonalne skierowane przeciwko receptorowi interleukiny 6 jest lekiem o udokumentowanej skuteczności i bezpieczeństwie leczenia u chorych na reumatoidalne zapalenie stawów.

Forum Reumatol. 2019, tom 5, nr 1: 8-13

Słowa kluczowe: reumatoidalne zapalenie stawów; tocilizumab; leczenie
Adres do korespondencji: dr n. med. Tomasz Dziewit Katedra i Klinika Chorób Wewnętrznych, Reumatologii i Immunologii Klinicznej Śląskiego Uniwersytetu Medycznego w Katowicach e-mail: wit1@op.pl

\section{WSTĘP}

Tocilizumab jest rekombinowanym humanizowanym przeciwciałem monoklonalnym skierowanym przeciwko receptorom interleukiny 6, zarejestrowanym do leczenia chorych na reumatoidalne zapalenie stawów (RZS), młodzieńcze idiopatyczne zapalenie stawów, chorobę Stilla u dorosłych i zapalenie olbrzymiokomórkowe tętnic. Lek blokuje przekazywanie sygnału drogą receptora interleukiny-6 i tym samym hamuje reakcję zapal- ną. Poza tym zwiększa ekspresję genów kodujących białka sprzyjające gojeniu uwalniane do płynu stawowego. Klinicznie wyraża się to zmniejszeniem zapalenia stawów i zapalenia ogólnoustrojowego, a także zmniejszeniem stężenia wskaźników fazy ostrej leczonych chorych $[1,2]$.

Skuteczność i bezpieczeństwo tocilizumabu w leczeniu chorych na RZS wykazano w kilku dużych badaniach klinicznych [1, 3, 4]. Lek jest dostępny w postaci dożylnej i podskórnej, wykazują one zbliżoną skuteczność [5-8]. 


\section{MATERIAŁ I METODY}

Doświadczenia ośrodka autorów artykułu w leczeniu tocilizumabem chorych na RZS datują się od 2012 roku. Zanim lek ten był wpisany na listę cząsteczek stosowanych w leczeniu RZS w programie lekowym NFZ „Leczenie chorych na RZS i MIZS o przebiegu agresywnym" autorzy stosowali go łącznie u pięciu pacjentów, finansując leczenie w ramach tak zwanych jednorodnych grup pacjentów (JGP). Spośród tych pacjentów do tej pory są leczone trzy osoby, z przerwami wynikającymi z uzyskiwanych remisji.

Ogółem w niniejszym ośrodku było objętych leczeniem tocilizumabem blisko 70 pacjentów. Obecnie (stan na styczeń 2019 r.) liczba leczonych aktywnie z powodu RZS wszystkimi cząsteczkami dostępnymi w programie lekowym NFZ wynosi ponad $160, \mathrm{z}$ czego u ponad 55 jest stosowany tocilizumab w obu dostępnych formach.

U 2 pacjentów uzyskano trwałą remisję, to znaczy nie wymagają oni kontynuacji leczenia modyfikującego przebieg choroby. Trzech pacjentów zmarło - nie ma informacji co do przyczyn zgonów, nie nastąpiły one jednak w trakcie leczenia tocilizumabem.

Leczenia tocilizumabem zaprzestano u jednej chorej, u której wystąpiła gruźlica prosówkowa, u kolejnej jednej osoby, u której rozpoznano raka tarczycy, oraz u jednej osoby, u której wykryto raka pęcherza moczowego.

Większość pacjentów leczonych tocilizumabem w ośrodku autorów artykułu otrzymało lek w tak zwanej drugiej linii leczenia w wyniku pierwotnej lub znacznie częściej wtórnej nieskuteczności leków w grupy inhibitorów czynnika martwicy nowotworów alfa (TNF-alfa, tumor necrosis factor alpha) lub rytuksymabu. Z czego na 54 pacjentów - 19 otrzymało tocilizumab po wtórnej lub pierwotnej nieskuteczności etanerceptu, 13 adalimumabu, 4 golimumabu, 6 certolizumabu, 8 infliksymabu i 4 rituksymabu (ryc. 1). Innymi przyczynami, dla których odstawiano preparat anty-TNF-alfa były: zaostrzenie niewydolności serca (III/IV stopień wg NYHA), reakcja alergiczna podczas wlewu infliksymabu, reakcje nadwrażliwości skórnej w trakcie leczenia etanerceptem i adalimumabem, pojawienie się łuszczycy krostkowej podczas stosowania etanerceptu.

Tocilizumab w pierwszej linii leczenia zastosowano u 7 pacjentów (stan na 12.2018 r.). Byli to głównie pacjenci z wyjściową dużą aktywnością zapalną wyrażającą się znacznym przyspieszeniem OB i zwiększonym stężeniem białka C-reaktywnego (CRP, C-reactive prote- in), niedokrwistością oraz zajęciem wielu stawów. Ponadto zastosowano ten lek w pierwszej linii leczenia u: 1 pacjentki z wysiękowym zapaleniem osierdzia w przebiegu RZS, u 2 pacjentów z chorobą Stilla u dorosłych z zajęciem stawów, u 1 pacjentki ze stwierdzaną demielinizacją ośrodkowego układu nerwowego w przebiegu RZS (po wykluczeniu pierwotnej choroby demielinizacyjnej), a także u 1 pacjentki w kontynuacji terapii, u której zapoczątkowano leczenie biologiczne tocilizumabem $\mathrm{w}$ badaniu klinicznym $\mathrm{z}$ użyciem tego leku w innym ośrod$\mathrm{ku}, \mathrm{z}$ potwierdzoną skutecznością tego leku.

Dziewięciu pacjentów otrzymało tocilizumab w III i IV linii leczenia, z czego większość po skórnych reakcjach alergicznych kolejno wyzwalanych podaniem adalimumabu i etanerceptu, a także utrzymujących się długotrwale zmniejszonych stężeniach immunoglobulin IgG i/lub IgM po zastosowaniu rituksymabu.

\section{TOCILIZUMAB A TERAPIA SKOJARZONA}

Analizując dane pacjentów leczonych w ośrodku (stan na 12.2018) wykazano, że większość (41/70) stosowała tocilizumab w monoterapii (bez metotreksatu), a tylko 29/70 łącznie z metotreksatem. Nie analizowano pacjentów w terapii skojarzonej z innymi lekami modyfikującymi przebieg choroby, ponieważ liczba takich chorych stosujących leflunomid, sulfasalazynę bądź leki przeciwzimnicze jest bardzo mała.

Co najmniej połowa pacjentów rozpoczynających leczenie tocilizumabem nie stosowało metotreksatu, natomiast liczba takich pacjentów zwiększała się w toku leczenia, ponieważ u chorych leczonych metotreksatem i tocilizumabem metotreksat odstawiano $\mathrm{z}$ różnych przyczyn. Współleczenia metotreksatem w większości przypadków zaprzestawano z powodu obserwowanej neutropenii bądź pacjenci sami rezygnowali z tego leku z powodu nietolerancji, głównie ujawniającej się zaburzeniami układu pokarmowego, bólami głowy, złym samopoczuciem lub osłabieniem. Należy podkreślić, że nie obserwowano po odstawieniu metotreksatu pogorszenia skuteczności leczenia tocilizumabem wyrażonego wskaźnikami aktywności choroby DAS28. Szacuje się, że u ponad połowy chorych, którzy rozpoczynali leczenie tocilizumabem $\mathrm{w}$ terapii skojarzonej $\mathrm{z}$ metotreksatem odstawiano ten lek toku leczenia w wyniku stwierdzanych przez lekarza zmian, najczęściej z powodu neutropenii lub z powodu nietolerancji metotreksatu, którą często zgłaszali pacjenci. 


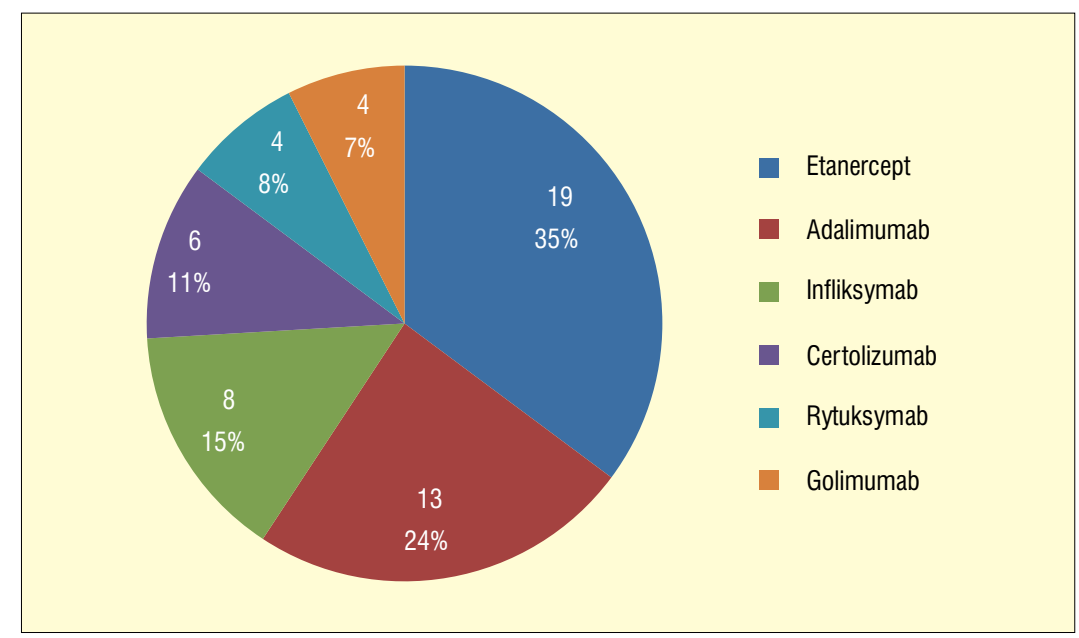

Rycina 1. Leki stosowane w pierwszej linii leczenia u chorych, którzy otrzymali w drugiej linii leczenia tocilizumab

\section{WYNIKI}

Analizując dane 53 pacjentów, którym podano lek po raz pierwszy, po 90 dniach leczenia tocilizumabem stwierdzono, że 30, czyli 57\% spośród nich, uzyskało umiarkowaną aktywność choroby ze średnią wartością DAS28 równą 3,77, niską aktywność choroby u 4 pacjentów (7\%), ze średnią wartością DAS28 równą 2,9, a remisję u 19 osób (36\%), ze średnią wartością DAS28 równą 1,85 .

Po 180 dniach leczenia u 50 analizowanych pacjentów stosujących tocilizumab po raz pierwszy niską aktywność choroby uzyskało 17 osób (34\%), ze średnią wartością DAS28 równą 2,8 i 33 osób uzyskało remisję (66\%), ze średnią wartością DAS28 równą 1,82 (ryc. 2).

Zwraca uwagę fakt, że w okresie pół roku wszystkie osoby osiągnęły co najmniej niską aktywność choroby, a większość z nich osiągnęło remisję.

$\mathrm{Z}$ kolei, analizując 51 pacjentów w kolejnych cyklach leczenia, to po pierwszych 90 dniach uzyskano umiarkowaną aktywność choroby w 20 przypadkach $(39 \%)$ ze średnią wartością DAS28 równą 3,0, niską aktywność choroby w 9 przypadkach $(17,7 \%)$ ze średnią wartością DAS28 równą 2,86 i remisję w 22 przypadkach $(43,3 \%)$ ze średnią wartością DAS 28 równą 1,7 .

Podobnie w analizie 47 przypadków po 180 dniach leczenia u pacjentów w kolejnych cyklach leczenia niską aktywność choroby uzyskano w 18 przypadkach $(38,3 \%)$ ze średnią wartością DAS28 równą 2,88 i remisję w 29 przypadkach $(61,7 \%)$ ze średnią wartością DAS28 równą 1,73 (ryc. 3).

Należy podkreślić, że jak dotąd (dane z 01.2019) u żadnego z leczonych pacjentów

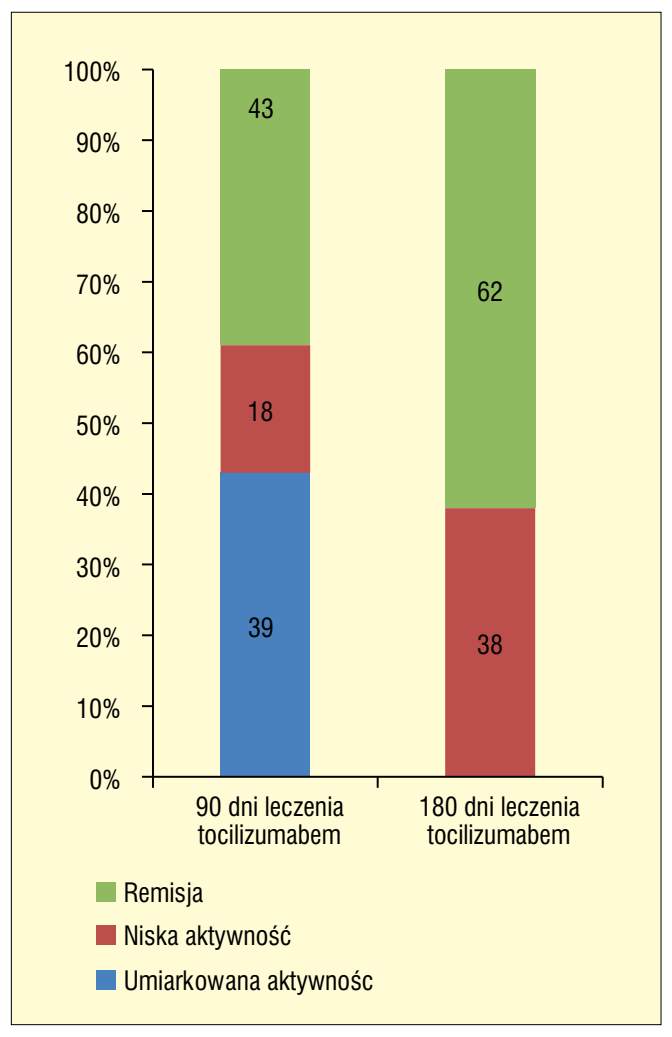

Rycina 2. Aktywność choroby po 90 i 180 dniach leczenia tocilizumabem u 53 i 50 analizowanych pacjentów po pierwszym podaniu leku

w ośrodku autorów pracy nie odstawiono tocilizumabu z powodu braku lub utraty skuteczności.

\section{CZAS UTRZYMYWANIA SIE REMISJI/NISKIEJ AKTYWNOŚCI CHOROBY PO ZAKOŃCZENIU LECZENIA TOCILIZUMABEM}

Analizowano 57 przypadków remisji/niskiej aktywności choroby i czas pozostawania 


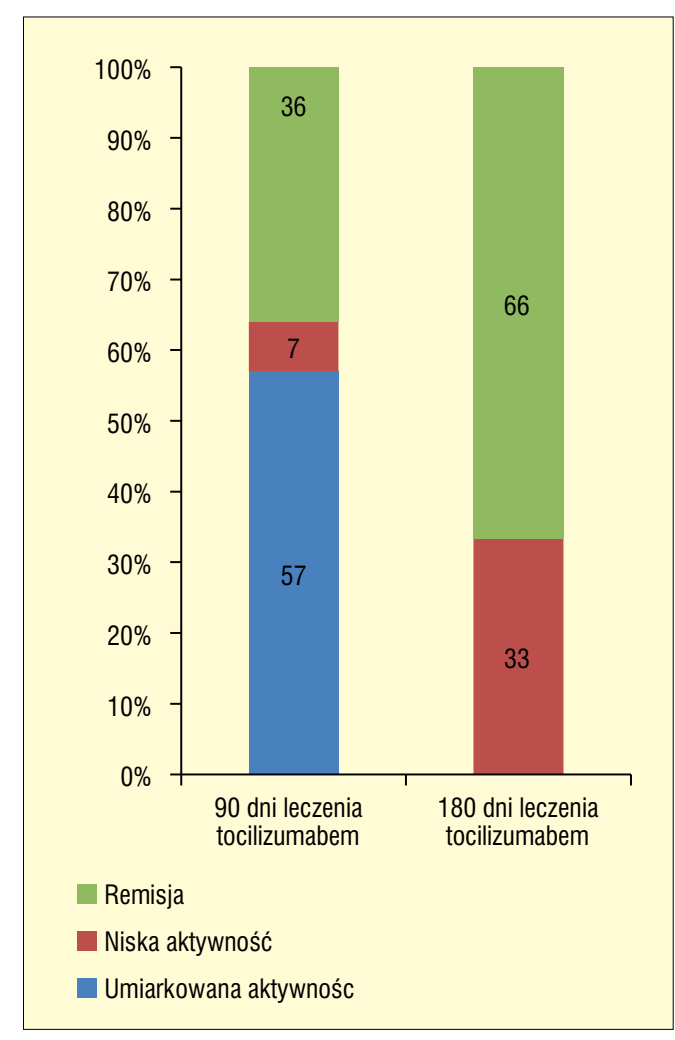

Rycina 3. Aktywność choroby po 90 i 180 dniach leczenia tocilizumabem u kolejno 51 i 47 analizowanych pacjentów po następnych dawkach leku

bez leczenia modyfikującego tocilizumabem. $\mathrm{Na}$ podstawie tych danych wynosił on od 18 dni do blisko 4 lat. Średni czas pozostawania w remisji/niskiej aktywności choroby u opisywanych pacjentów to około 5 miesięcy. W praktycznym podejściu do pacjentów po zakończeniu cyklu leczenia tocilizumabem zalecano kontynuację leczenia metotreksatem lub innym syntetycznym lekiem modyfikującym przebieg choroby, w przypadku kiedy z powodu wcześniej występującej leukopenii metotreksat odstawiano proponowano ponowne stosowanie leku, co wydaje się wydłużało okres w pozostawania w remisji bez leku biologicznego.

\section{DZIALANIA NIEPOŻĄDANE TOCILIZUMABU}

Tocilizumab jest lekiem bardzo dobrze tolerowanym, nie odnotowano poważnych działań niepożądanych podczas opisywanej terapii. Do najczęściej występujących, obserwowanych u niniejszych chorych, działań niepożądanych należy leukopenia $\mathrm{z}$ neutropenią łagodną obserwowaną głównie na początku leczenia (w ciągu pierwszych kilku miesięcy stosowania leku). Neutropenia nie wiązała się nigdy z po- wikłaniami w postaci zakażeń, najczęściej była krótkotrwała. W postępowaniu z neutropenią stosowano: odstawienie metotreksatu lub innych leków modyfikujących przebieg choroby, polecenia ograniczenia i/lub całkowitego zakazu zażywania leków przeciwbólowych, przeciwzapalnych, ewentualnie zastosowanie glikokortykosteroidów. W przypadkach neutropenii poniżej $1000 / \mathrm{mm}^{3}$ stosowano, zgodnie z charakterystyką produktu leczniczego, bądź zmniejszenie dawki leku do $4 \mathrm{mg} / \mathrm{kg}$ masy ciała, bądź czasowe zaprzestanie leczenia do czasu normalizacji parametrów białokrwinkowych. We wszystkich przypadkach neutropenia miała charakter przejściowy, co umożliwiało powrót do leczenia tocilizumabem i na ogół nie występowała ponownie. Nie stwierdzono u żadnego z pacjentów zmniejszonej liczby płytek krwi.

Obserwowano również zakażenia, najczęściej łagodne, dotyczące górnych dróg oddechowych, rzadziej dróg moczowych i przewodu pokarmowego. Częstość występowania łagodnych zakażeń była w odczuciu autorów pracy porównywalna $\mathrm{z}$ tą $\mathrm{w}$ populacji osób zdrowych. Sporadycznie pojawia się opryszczka wargowa. Trzykrotnie odnotowano objawy półpaśca, nie obserwowano półpaśca ocznego.

Bardzo rzadko występowały zwiększone aktywności transaminaz. Stosunkowo rzadko obserwowano zwiększone stężenia cholesterolu całkowitego i cholesterolu frakcji LDL. W takich przypadkach postępowano w sposób typowy, zalecając pacjentom stosowanie statyn, uzyskując początkowo stabilizację, a następnie zmniejszanie się stężeń badanych lipidów, co było rejestrowane w kolejnych oznaczeniach lipidogramu rutynowo wykonywanych podczas ocen monitorujących przebieg leczenia.

W jednym przypadku wystąpiły objawy guza zapalnego jelita grubego wymagającego operacji, w przebiegu choroby uchyłkowej.

\section{TOCILIZUMAB W FORMIE PODSKÓRNEJ}

Od maja 2018 roku w swoim ośrodku autorzy rozpoczęli leczenie swoich pacjentów tocilizumabem $\mathrm{w}$ formie podskórnej. Aktualnie ponad połowa wszystkich pacjentów leczonych tocilizumabem stosuje tę formę leku. Przechodząc na formę podskórną, u pacjentów dokonywano wyboru, kierując się stabilnym przebiegiem choroby, brakiem innych współistniejących chorób i/lub stanów, które miałyby wpływ na leczenie, na przykład stanem kadriologicznym pacjentów, objawami ogólnymi wcześniej występującymi, niedo- 
krwistością, nawracającą leukopenią, a także wolą pacjenta.

Ze względu na stosunkowo krótki czas stosowania nie dokonywano analizy statystycznej, ale na podstawie dotychczasowych doświadczeń z tą formą leku, nie obserwuje się pogorszenia skuteczności. Pacjenci dobrze tolerują lek. U tych, u których lek podskórny stosowano w kontynuacji formy dożylnej, utrzymuje się dobra odpowiedź na leczenie. Natomiast u pacjentów, u których zastosowano lek w formie podskórnej po raz pierwszy, podobnie jak to miało miejsce w przypadku formy dożylnej, uzyskiwano dobre odpowiedzi na leczenie. Tylko w jednym przypadku wycofano się z formy podskórnej leku i na powrót zastosowano lek podawany dożylnie, była to osoba, u której wystąpiły wcześniej silne reakcje skórne po zastosowaniu adalimumabu i etanerceptu.

\section{DYSKUSJA}

$\mathrm{Na}$ podstawie własnych doświadczeń w podsumowaniu autorzy stwierdzają, że tocilizumab jest niezwykle skutecznym i cennym lekiem u chorych na RZS, pozwalającym na szybkie uzyskiwanie niskiej aktywności choroby, jak również efektywnym w długoczasowym stosowaniu. U żadnego z pacjentów, którzy rozpoczęli leczenie tocilizumabem nie zaprzestano leczenia $z$ powodu utraty skuteczności leku, co jest zgodne z wynikami wielu badań klinicznych [3, 4]. Cechuje go duży profil bezpieczeństwa i mały odsetek powikłań i działań niepożądanych. Więcej niż połowa badanych pacjentów otrzymuje tocilizumab w monoterapii co nie przekłada się na pogorszenie skuteczności leczenia, co jest to potwierdzeniem danych płynących $\mathrm{z}$ badań klinicznych [6, 7, 9].

Podobnie jak w przypadku innych leków biologicznych forma podskórna tocilizumabu stosunkowo rzadko może powodować reakcje nadwrażliwości [10], jak ma to miejsce u prawie wszystkich opisywanych pacjentów stosujących tę nową formę leku.

\section{WNIOSKI}

Doświadczenia własne uzyskane $\mathrm{z}$ badania stosunkowo małej liczby chorych, ale odzwierciedlające praktykę lekarską (tzw. real world data) są zgodne z wynikami badań klinicznych i potwierdzają, że tocilizumab, rekombinowane humanizowane przeciwciało monoklonalne skierowane przeciwko receptorowi interleukiny 6 jest lekiem o udokumentowanej skuteczności i bezpieczeństwie leczenia u chorych na reumatoidalne zapalenie stawów.

\section{ABSTRACT}

Introduction: The study summarized experience of the Department of Internal Medicine, Rheumatology and Clinical Immunology of the Medical University of Silesia in Katowice in management of patients with rheumatoid arthritis with tocilizumab from 2012 to 2019.

Material and methods: About 70 patients were treated with tocilizumab, and currently more than 50 of them are receiving the medication. Tocilizumab is administered to most of patients as a second biological drug, after failure in medication with TNF-alpha inhibitors.

Results: Positive response to the treatment was observed in all of patients within the first 90 days of medication. Low disease activity or remission lasted for all period of treatment both in patients receiving concomitantly methotrexate or those treated with tocilizumab only. A small number of adverse reaction to medication was recorded .

Conclusions: A single centre experience based on relatively small number of patients but depicting so called real world data are concordant with results of clinical trials and confirmed that recombinant humanized monoclonal antibody against interleukin-6 receptor, tocilizumab is an effective and safe therapy for patients with rheumatoid arthritis.

Forum Reumatol. 2019, tom 5, nr 1: 8-13

Key words: rheumatoid arthritis; tocilizumab; treatment

\section{Piśmiennictwo}

1. Scott LJ. Tocilizumab: Review in rheumatoid arthritis. Drugs. 2017; 77(17): 1865-1879, doi: 10.1007/s40265-0170829-7, indexed in Pubmed: 29094311.

2. Mihara M, Kasutani $K$, Okazaki M, et al. Tocilizumab inhibits signal transduction mediated by both mIL-6R and sIL-6R, but not by the receptors of other members of IL-6 cytokine family. Int Immunopharmacol. 2005; 5(12): 1731-1740, doi: 10.1016/j. intimp.2005.05.010, indexed in Pubmed: 16102523.

3. Jones G, Wallace T, McIntosh M, et al. Five-year efficacy and safety of tocilizumab monotherapy in patients with rheumatoid arthritis 
who were methotrexate- and biologicnaive or free of methotrexate for 6 months: the AMBITION Study. The Journal of Rheumatology. 2016; 44(2): 142-146, doi: 10.3899/jrheum.160287.

4. Genovese MC, Rubbert-Roth A, Smolen JS, et al. Longterm safety and efficacy of tocilizumab in patients with rheumatoid arthritis: a cumulative analysis of up to 4.6 years of exposure. J Rheumatol. 2013; 40(6): 768-780, doi: 10.3899/jrheum.120687, indexed in Pubmed: 23457383.

5. Atsumi T, Fujio K, Yamaoka K, et al. Safety and effectiveness of subcutaneous tocilizumab in patients with rheumatoid arthritis in a real-world clinical setting. Mod Rheumatol. 2018; 28(5): 780-788, doi: 10.1080/14397595.2017.1416760, indexed in Pubmed: 29251032.

6. Nakashima $\mathrm{Y}$, Kondo M, Miyahara $\mathrm{H}$, et al. Drug delivery options to increase patient adherence and satisfaction in the management of rheumatoid arthritis -- focus on subcutaneous tocilizumab. Drug Des Devel Ther. 2014; 8: 913-919, doi: 10.2147/DDDT.S52099, indexed in Pubmed: 25045250.

7. Abdallah H, Hsu JC, Lu P, et al. Pharmacokinetic and pharmacodynamic analysis of subcutaneous tocilizumab in pa- tients with rheumatoid arthritis from 2 randomized, controlled trials: SUMMACTA and BREVACTA. J Clin Pharmacol. 2017; 57(4): 459-468, doi: 10.1002/jcph.826, indexed in Pubmed: 27599663.

8. McLaughlin M, Östör A. Safety of subcutaneous versus intravenous tocilizumab in combination with traditional disease-modifying antirheumatic drugs in patients with rheumatoid arthritis. Expert Opin Drug Saf. 2015; 14(3): 429-437, doi: 10.1517/14740338.2015.998198, indexed in Pubmed: 25553607.

9. Kremer JM, Rigby W, Singer NG, et al. Sustained response following discontinuation of methotrexate inpatients with rheumatoid arthritis treaed with subcutaneous tocilizumab: results from a randomized, controlled trial. Arthritis rheumatol. 2018; 70: 1200-1208.

10. Yun $H$, Xie F, Beyl RN, et al. Risk of hypersensitivity to biologic agents among medicare patients with rheumatoid arthritis. Arthritis Care Res (Hoboken). 2017; 69(10): 1526-1534, doi: 10.1002/acr.23141, indexed in Pubmed: 27813327 